\title{
Sustainable Development of Surplus By-Products of the Agri-Food Chain with the Purpose of Reducing Environmental Damage
}

\author{
Amalia Cabrera Nunez ${ }^{1, *}$, Miguel Angel Lammoglia Villagomez ${ }^{1}$, Cesar Enrique Martinez Sanchez ${ }^{1}$, Maria Rebeca Rojas Ronquillo ${ }^{1}$, Analy Elsa \\ Bello Velasquez ${ }^{1}$, Flor Maria Montero Solis ${ }^{1}$, Sergio Omar Nieto Rosaliano ${ }^{1}$
}

${ }^{1}$ Department of Biological and Agricultural Sciences, Universidad Veracruzana, Tuxpan, Mexico

*Corresponding author: Amalia Cabrera Nunez, Department of Biological and Agricultural Sciences, Universidad Veracruzana, Tuxpan, CP 92890, Mexico, Phone: 017838344350 ext. 46109; E-mail: amacabrera@uv.mx

Received: 03 Aug, 2021 | Accepted: 19 Aug, 2021 | Published: 26 Aug, 2021

Citation: Nunez AC, Villagomez MAL, Sanchez CEM, Ronquillo MRR, Velasquez AEB, et al. (2021) Sustainable Development of Surplus By-Products of the Agri-Food Chain with the Purpose of Reducing Environmental Damage. J Anim Sci Res 5(2): dx.doi.org/10.16966/2576-6457.152

Copyright: (C) 2021 Nunez AC, et al. This is an open-access article distributed under the terms of the Creative Commons Attribution License, which permits unrestricted use, distribution, and reproduction in any medium, provided the original author and source are credited.

\section{Abstract}

The global food industry annually generates millions of tons of by-products derived from the processing and manufacturing of citrus fruits. Only a small part is used to obtain new products and the rest is considered as waste, with the consequent negative impact on the environment. The purpose of this research work is to use the products extracted from citrus fruits of orange, grapefruit, tangerine and lemon, being used in the diet of ruminants as a source of energy, supplement or alternative in the face of a shortage of forage. Making the use of these by-products in order to reduce the environmental impact of the waste generated.

Keywords: By-products; Citrus; Sustainable; Environmental pollution

\section{Introduction}

Between 1970 and 1995 the land lost 30\% of its natural wealth (forest, marine and freshwater resources). Mostly caused by the indiscriminate use of the consumption of its resources and the pollution of the environment. The main reasons for this deterioration have been due to population growth and increased economic activity. Among the main causes mentioned is the consumption of certain renewable resources such as cereals, meat of animal origin, fish, shellfish, wood, paper, which are used by all the world's inhabitants for food, fuel and materials [1]. Likewise, the impact that the excessive use of artificial fertilizers has on the biosphere, the emissions of carbon dioxide in the atmosphere (produced by the use of fossil fuels such as coal, oil and gas), causing the greenhouse effect and global warming [2].

It is important to mention that what has to do with natural forest cover has been in decline. At present it is mentioned that about $10 \%$ during these 25 years, representing the disappearance of 150 thousand square kilometers annually. In order to maintain the sustainability of natural resources, scientists at a global level have proposed a series of actions that help in our days to mitigate an indiscriminate man-made damage [3].

It is therefore necessary to use natural resources efficiently, for economic activity to maintain or improve the environmental system together with the quality of life, promote maximum recycling and reuse, propose the implementation of clean technologies (wind farms, solar power plants, wave energy, solar bike path, electric vehicles), restore damaged ecosystems (biodegradable garbage, inorganic garbage recycling, ecotourism), encourage regional self-sufficiency, recognize the importance of nature for human well-being, use of rainwater and the use of an ecological agriculture. And above all, expand the application of more energy-efficient technologies and eliminate energy loss in transport, industry and the home [4].

World citrus production reaches almost 99 million tons according to provisional data estimated by FAO. Taking citrus fruits as a whole, the main producer is Brazil, whose production is more than 19 million tons $(19,349,000)$, which represents around 20\% [5]. It is followed in order of importance by the United States with a production of almost 15 million in the same year and equivalent to $16 \%$. The third place is occupied by China with 10 million and Spain and Mexico contribute just over 5 million tons each. Citrus production is dominated by oranges, which represent $65 \%$; they are followed in order of importance by mandarins with 19\%, with lemons (11\%) and grapefruits (5\%) occupying third and fourth place, respectively [6].

The global food industry annually generates millions of tons of by-products derived from the processing and manufacturing of vegetables. Only a small part is used to obtain new products and the rest is considered as waste, with the consequent negative impact on the environment [7].

Fruits are foods with a low caloric intake, consisting mainly of water, as well as carbohydrates, fiber, proteins, lipids, vitamins and minerals, all of which are contained in different proportions depending on the type of fruit to be considered. Composed mainly of three fundamental parts, pulp, seed and peel, the pulp being the edible part most consumed by the general population and the peel 
the residual part of the food, since it is seldom used in various specific functions, such as: Preparation of pectin, substrates, composting, citrus flours, essential oils, as well as bioactive compounds with beneficial effects on health, such as fiber and polyphenols [8].

Citrus fruits have little-used potential. The use of these agricultural by-products is limited to the diet of cattle and recently in the feeding of red tilapia. However, these wastes are rich in essential oils and natural pigments that deserve to be used, to achieve a comprehensive use of the item. Among the natural pigments present in orange waste are carotenoids, which are very important since they represent a source of provitamin A ( 1 equivalent of retinol $=1 \mathrm{~m}$ of retinol $=6 \mathrm{mg}$ of beta carotene), they are not toxic, they present within the cell antioxidant activity, participate in the deactivation of free radicals produced in cell metabolism, impart yellow and red colors to plants and animals [9]. Some nutritional characteristics of these citrus fruits can be described.

1) Orange: It belongs to the Citrus genus of the Routine family. It is one of the most consumed fruits in the world. It contains a high amount of vitamins, and has the reputation of being the queen of vitamin C, the country with the highest production is Brazil, followed by the United States and Mexico. 2) Lemon: Both the lime and the lemon are citrus fruits of the Citrus genus belonging to the Routine family. There are numerous varieties within this group: lunario, verna, waiter (fine or primofiori), real, verdelli (Italian), eureka (California) and femminello among others. They are grown in all tropical and subtropical regions of the world: Italy, Spain, Portugal and the United States mainly. As it matures, it is transformed, changing its composition and improving its quality. 3) Mandarin: It also belongs to the Citrus genus of the Rutaceae family. They are smaller in size than oranges, with a more flattened shape and more grainy skin. This citrus comes from the tropical areas of Asia, especially China. 4) Grapefruit: It belongs to the Citrus genus of the Rutaceae family. There are two very different varieties, both of which are very aromatic [10].

Therefore, this research aims to use the by-products extracted from citrus fruits of orange, grapefruit, mandarin and lemon, being used in the diet of ruminants as a source of energy, supplement or alternative in the face of a shortage of forage. Making the use of these by-products generating a sustainable development of surplus by-products of the agri-food chain in order to reduce environmental damage.

\section{Method Description}

This research was developed in a commercial ranch in the north of the state of Veracruz, in the Municipality of Álamo, Temapache, Veracruz; geographically located in the meridians: north latitude $20^{\circ}$ $55^{\prime} 19^{\prime \prime}$, west longitude $97^{\circ} 41^{\prime} 44^{\prime \prime}$, at an altitude of 140 meters above sea level and average annual temperature of 19 to $38^{\circ} \mathrm{C}$. Aiming to carry out a bibliographic search of the main agro-industrial by-products that are discarded by various industries in rivers, streams, seas, forests, among others, causing damage to the environment.

Which, to mitigate this environmental pollution, will be used in the diet of domestic animals achieving the sustainability of these byproducts. Likewise, a nutritional evaluation of the citrus by-products (peel, bagasse and pulp) was carried out, for every 100 grams of product and the other ingredients (cereals and protein) that are used in the food rations of ruminants. A Wendi analysis was carried out in the Animal Bromatology laboratory of the Faculty of Biological and Agricultural Sciences of the Veracruzana University, Tuxpan campus. Determining the following nutritional values: Crude Protein\%, Fiber\%, Calories Kcal, Vitamin C mg, Potassium mg, Calcium mg, Folic Acid mg, Vitamin A UI.
Based on the nutritional studies obtained from citrus by-products, food rations were prepared as an energy alternative in the daily diet of grazing ruminants in star grass, consuming $2.5 \%$ (NRC, 2007) of their live weight during the 90 days of the trial. Forty dual-purpose calves (Zebu x European Swiss) were used, weighing approximately $300 \mathrm{~kg}$ at 30 months of age, which remained in an area of 40 hectares established with brizantha grass (brachiara brizantha).

An analysis of variance and Duncan's test were performed to compare the treatment means $(\mathrm{P}<0.05)$, with the SPSS statistical package (SPSS, version 10).

\section{Results and Discussions}

Citrus pulp is described as a common by-product in various countries around the world and its cost is relatively low compared to its nutritional value. These by-products contain a high percentage of pectin and soluble carbohydrates, and for these reasons it has been used to replace cereals in ruminant diets. The northern region of the state of Veracruz, Mexico has agroindustrial residues and by-products (Table 1), capable of being used as food ingredients in times of nutritional deficit of livestock kept in natural pastures.

As can be seen in tables $1 \& 2$, Citrus by-products cover all the possible characteristics that can be found in conventional foods (forages and concentrates), so the general evaluation criteria are similar and must attend to their energy value, their protein value and

Table 1: Main agro-industrial by-products used in food rations for domestic animals.

\begin{tabular}{|c|c|c|c|c|}
\hline Source & MS\% & PC\% & FC\% & Mcal/Kg DM \\
\hline \multicolumn{5}{|c|}{ Cereal Byproducts } \\
\hline Molasses & 75 & 3.5 & 6.7 & 2.7 \\
\hline Wheat bran & 89 & 17.4 & 11.2 & 3.43 .5 \\
\hline Bakery sweep & 92 & 11.2 & 1.4 & 2.5 \\
\hline Orange peel & 91 & 6.7 & 12.7 & 3.8 \\
\hline $\begin{array}{l}\text { Cereals (corn, wheat, } \\
\text { sorghum, barley) }\end{array}$ & 89 & 10.0 & 2 & 2.3 \\
\hline Banana stem and fruit & 87 & 4.2 & 1 & 2.3 \\
\hline Pineapple in shell and fruit & 92 & 4.6 & 1 & \\
\hline \multicolumn{5}{|c|}{ Protein By-products } \\
\hline Soybean paste & 89 & 48 & 5.0 & 3.4 \\
\hline Cotton paste & 92 & 45 & 13.3 & 2.8 \\
\hline Coconut pate & 91 & 21 & 15.4 & 2.6 \\
\hline Coffee pulp & 92 & 20.0 & 23.79 & 2.03 .2 \\
\hline Fish flour & 94 & 71 & 0.7 & 2.1 \\
\hline Leucaena flour & 88 & 24.3 & 15.78 & 2.6 \\
\hline Meat flour & 92 & 55 & 28 & 2.4 \\
\hline Bird feather meal & 91 & 89 & 3.0 & ----- \\
\hline Urea & 99 & 280 & ------ & \\
\hline \multicolumn{5}{|c|}{ Sun products of animal origin } \\
\hline Milk serum & 6.8 & 11 & 12.0 & 1.4 \\
\hline Chicken manure & 88 & 28 & 20.0 & 1.7 \\
\hline Chick & 84 & 24 & 38.0 & 2.1 \\
\hline Bovine manure & 28 & 11 & 23.2 & 1.4 \\
\hline
\end{tabular}

MS: Dry Matter, PC: Crude Protein, FC: Crude Fiber, Mcal/Kg DM 
the maximum amount of them that animals can consume or voluntary ingestion [11]. In this sense, although the information available is still insufficient and sometimes confusing, the adequate interpretation of the existing data facilitates the rational use of these resources for the feeding of ruminants. Each region of the country, according to its agroecological characteristics, generates defined by-products, standing out in: cotton seed, rice bran, malt feces and citrus residues, among others. In different regions of the country, by-products are part of the daily diet of animals, but the importance of some of them as a strategic food resource for cattle has yet to be clarified, such as those obtained from the industrialization of citrus: bagasse, pulp, or shell and seed each having its own characteristics of conservation, humidity, and percentages of proteins, lipids and carbohydrates [12].

These residues produced in the juicers of the northern zone of Veracruz are normally thrown into the rivers, lakes, dams or streams of the locality; Therefore, the ecological-environmental problem produced by the difficulty of handling large volumes of industrial waste with high moisture content, which makes its storage difficult, could be mitigated with the immediate use of the aforementioned residue in the preparation of food rations for ruminants (Table 3 ).

Based on the recommendations of the National Research Council [13], the amount of citrus by-product (orange, tangerine, lemon, grapefruit, and lime) recommended in the rations for ruminants is from $20 \mathrm{~kg}$ to $80 \mathrm{~kg}$, to be used by the ruminal microflora and maintain a neutral $\mathrm{pH}$ ( 6.5 to 7$)$. To obtain balanced rations, ingredients such as cereals, protein and animal origin are taken into account, described in table 3. As can be seen, this ration contains $50 \mathrm{~kg}$ of citrus by-product, providing $16.15 \%$ of Crude Protein. Meeting the range of protein intake from $10.0 \%$ to $18.0 \%$ established by the NRC.

In table 4 , it can be seen that the consumption in $\mathrm{Kg}$ of the concentrate, a significantly higher increase $(\mathrm{p} \leq 0.05)$ of $11,340 \mathrm{Kg}$ and a relative gain of $.866 \mathrm{gr}$ was observed. Which represents that this citrus-based by-product is economical and with favorable productive yields for grazing cattle.

An experience carried out in some agricultural production systems speaks eloquently of its possibilities of use in feeding livestock. On this occasion, different rations were compared in batches of steers, concluding that the dried citrus pulp plus the addition of proteins constitutes an excellent resource. Even if half of the pulp is replaced by grain sorghum, similar values of daily gain per animal are obtained [14]. Within the bibliography consulted, we found works with experimental conditions, in which trials stand out, with which we could discuss, resulting in those in which the category of calves at weaning is used since they are animals with nutritional requirements based on the needs of the NRC. One of the works carried out is the one carried out at the Agricultural Research Institute of Nicosia, Cyprus,

Table 2: Nutritional value of citrus by-products.

\begin{tabular}{|c|c|c|c|c|c|c|c|c|}
\hline Citrus By-Product & Protein & Fiber & Calories & Vitamin C & Potassium & Calcium & Folic Acid & Vitamin A \\
\hline Orange peel & $7.3 \%$ & $2.3 \mathrm{~g}$ & $46 \mathrm{Kcal}$ & $50.6 \mathrm{mg}$ & $165 \mathrm{mg}$ & $41 \mathrm{mg}$ & $38.7 \mathrm{ug}$ & $33.6 \mathrm{IU}$ \\
\hline Tangerine bag & $6.4 \%$ & $1.8 \mathrm{~g}$ & $45 \mathrm{Kcal}$ & $32 \mathrm{mg}$ & $150 \mathrm{mg}$ & $34.5 \mathrm{mg}$ & $21.8 \mathrm{ug}$ & $65 \mathrm{IU}$ \\
\hline Lemon peel & $5.0 \%$ & $4.7 \mathrm{~g}$ & $28 \mathrm{Kcal}$ & $51 \mathrm{mg}$ & $170 \mathrm{mg}$ & $11 \mathrm{mg}$ & $6.3 \mathrm{ug}$ & $0.6 \mathrm{IU}$ \\
\hline Pomelo bagaza & $7.4 \%$ & $1.6 \mathrm{~g}$ & $38 \mathrm{Kcal}$ & $36 \mathrm{mg}$ & $148 \mathrm{mg}$ & $23 \mathrm{mg}$ & $14 \mathrm{ug}$ & $1.8 \mathrm{IU}$ \\
\hline Lime pulp & $6.5 \%$ & $2.8 \mathrm{~g}$ & $22 \mathrm{Kcal}$ & $44 \mathrm{mg}$ & $82 \mathrm{mg}$ & $13 \mathrm{mg}$ & $10 \mathrm{ug}$ & $1.7 \mathrm{IU}$ \\
\hline
\end{tabular}

Own source/2021

Table 3: Ingredients used for feed rations for ruminants based on orange by-products and their protein percentage value (PC\%).

\begin{tabular}{|c|c|c|c|}
\hline Ingredients & Kg & PC\% & Total PC\% \\
\hline Citrus by-product & 50 & 10 & 5.10 \\
\hline Harinoline & 20 & 43 & 8.6 \\
\hline Groundsorghum & 25 & 12 & 2.45 \\
\hline Vitamins y Minerals & 5 & ----- & ---- \\
\hline Total & 100 & & $16.15 \%$ \\
\hline
\end{tabular}

Own source/2021. Kg: Kilograms, PC: Crude protein

Table 4: Productive returns in dual-purpose calves.

\begin{tabular}{|c|c|}
\hline Study Variables & Results \\
\hline Starting weight $(\mathrm{kg})$ & $300 \mathrm{a}$ \\
\hline Final weignt $(\mathrm{kg})$ & $378 \mathrm{a}$ \\
\hline Kg Gained/animal 90 days/Group & $78.0 \mathrm{a}$ \\
\hline Gained of weight/day (Kg) & $0.866 \mathrm{a}$ \\
\hline Food consumption (kg) & 11.340 \\
\hline
\end{tabular}

a trial in which 44 calves were kept for a period of 48 weeks, feeding them with a ration containing 60 dried orange pulp \%, to check its value in the substitution of barley grain for the energy supply. The results obtained showed that the citrus-based supplement behaves as a good substitute for said cereal [15].

Other studies carried out showed that 8-6month-old Brangus calves were fattened in a pen using a dry matter-based ration of $53 \%$ malt, $42 \%$ citrus pulp and 5\% molasses. The average daily gain was $940.2 \pm 195.2 \mathrm{~g} / \mathrm{day}$, which indicates the potential of these byproducts in feeding animals in feed lot. Any attempt to promote livestock production requires, among other aspects, to make a rational use of existing food resources [16]. Among these resources, special consideration has recently been given to agro-industrial by-products, whose availability and price make them attractive products, especially in those areas where natural forages are insufficient [17].

\section{Conclusion}

At present, in addition, the interest in its use is not only economic, but also ecological, because the increase in the production of crop plant residues, animal excreta and residues from the canning and processing industries causes a major environmental pollution problem. 
One of the main factors that today contribute to maintaining the quality of the environment is the use of agro-industrial by-products. Therefore, it is a priority to look for alternative nutritional sources that allow reducing costs without adversely affecting production. In relation to the above, the supplements must contain energetic, nitrogenous and mineral nutrients, but the levels of these components must vary according to the nutritional characteristics of the by-products and the daily requirements of the animals since this varies according to the species, sex, live weight, physiological stage and production level [18].

Undoubtedly, the supply of citrus fruits is a very favorable alternative for the farmer, not only because of the energy and protein inputs (when ensiling), but also because it is an economical option when other types of supplements are very expensive. This technology is an activity that generates sustainability for livestock productions, generates work for the area where they are produced, they are profitable technologies for the producer and it is a clean technology that favors the environment. Making silage cores is an easy-to-make practice to preserve highly perishable and watery products for long periods of time, using harvest by-products or agro-industrial residues when there are harvests or high productions.

\section{References}

1. FAO (2000) Overview of the World Economy, Commodity Prices and Export Revenues 45-48.

2. Benas C, Grigera Naon JJ, Monje A, Galli I, Acosta A, et al. (2007) Comparison of two body condition scales and their relationship with objective measures taken in cows. Arg J Anim Prod 17-4.

3. Ghisi JJM (2018) Citrus pulp in cattle feed. 1-6.

4. Gomez Cabrera A, Molino Alcaide E, Garrido Varo A, Edits A (2009) New sources of food for animal production-III. 45-52.

5. Fonaiap (1986) The cultivation of the sweet orange. Technological Packages Series №3-02, Maracay 140.

6. Food and Agriculture Organization of the United Nations (FAO) (2007) New forage resources. FAO Study: Anim Prod Health 4: 78-90.

7. Kuvera JC, Nazar Balboa H, Alfaro Ramos MA (2003) Use of dehydrated citrus pulp in ruminant feeding. Biotam 5: 1-5.
8. Hadjipanayiotou M, Louca A (2007) A note on the value of dried citrus pulp and grape marcas barley replacement in calf fattening diets. Anim Prod 23: 129-132.

9. Scerra V, Caparra P, Foti F, Lanza M, Priolo A (2001) Citrus pulp and wheat straw silaje as an ingredient in lamb diets: effects on growth and carcass and meat quality. Small Rumin Res 40: 51-56.

10. Moreno-Álvarez MJ, Gómez C, Mendoza J, Belen D (1994) Determination of total carotenoids in industrial orange peel waste Citrus sinensis var. Valencia in the West of Carabobo, Venezuela. 39.

11. Henríquez M (1995) Analysis of some components in the Citrus sinesis L. orange market 94.

12. Rosales M, Jaffe W (1981) Perspectives of the use of agricultural residues and agro-industrial wastes in Venezuela. CIEPE Editions 129.

13. NRC (National Research Council) (2007) Nutritional Requirements for ruminants in fattening. $7^{\text {th }}$ Edition Natl Acad Washington DC 1134.

14. https://www.abebooks.com/9780309317023/NutrientRequirements-Beef-Cattle-Eighth-0309317029/plp

15. Hofer CC, Galli LO (2001) Citrus pulp in diets for early weaned calves. Anim Prod 3.

16. Alibes X, Tisserand JL (2000) Mediterranean Agronomic Institutes. Tables of nutritional value for ruminants of forages and by-products. ETSIA. Cordoba, Spain. 123-128.

17. https://agris.fao.org/agris-search/search.do?recordID=QC9165001

18. Avilan L, Leal F, Bautista D (1989) Fruit growing manual. America, Caracas. 1316-1317.

19. Balbuena $O$ (2008) Technology available in the NEA for the supplementation of grazing cattle. NEA and Mercosur Regional Beef Day-35-37.

20. Basso C, Leal F, Sergent E (2011) The citrus. Guide of the Chair of Agronomic Management of fruits and species. Agronomy Department, Faculty of Agronomy. 37. 